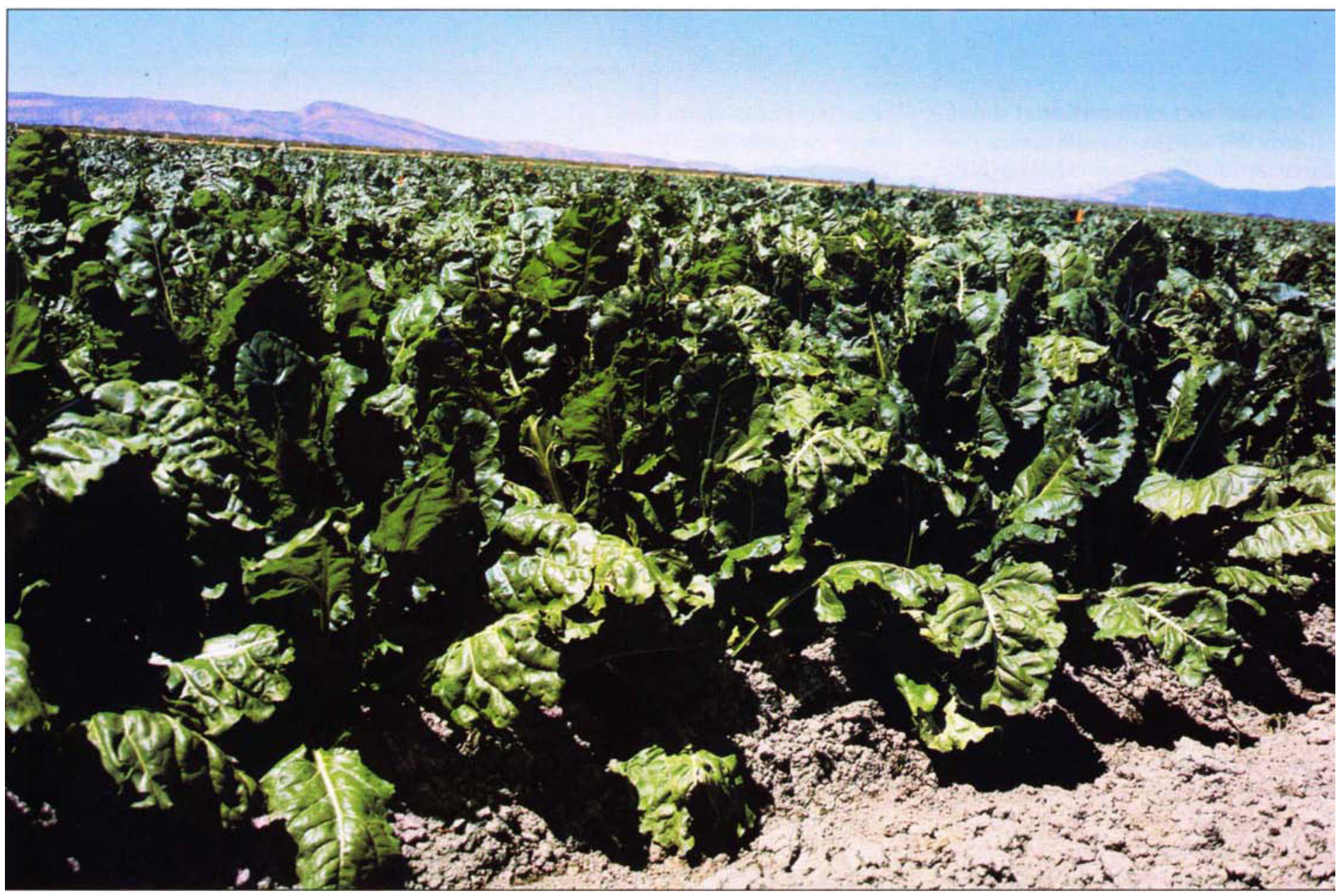

\title{
Reducing fertilizer in sugarbeets can protect water quality
}

\author{
Stephen R. Kaffka $\quad$ Don Kirby $\sqsupset \quad$ Gary R. Peterson
}

The loss of nutrients from fertilizers can impair surface and ground waters. Environmentally sensitive crop management requires applying only enough fertilizer to ensure economic crop yields. We found that sugarbeets grown in soils rich in organic matter in the Upper Klamath Basin can be fertilized at very low rates and used to remove more nutrients in harvested roots than are applied as fertilizer. This in turn reduces the risk of leaching excess nutrients and may help protect surface waters in the region from additional enrichment.
The Upper Klamath Basin, which
straddles the California-Oregon border, is an arid region with about 220,000 irrigated crop acres, primarily in potatoes, onions, hay, pasture and sugarbeets. By 2004, water-quality protection standards mandated by the Clean Water Act must be established for the Klamath River below Upper Klamath Lake. At that point, water from the U.S. Bureau of Reclamation's Klamath Project is returned to the river, combining drainage water from federal wildlife refuges and private farms in California and Oregon. These standards, called total maximum daily loads (TMDLs), are likely to include nutrients (such as nitrogen $[\mathrm{N}]$ and phosphorus $[\mathrm{P}]$ ), salts, temperature, pesticides, unionized ammonia and perhaps other contaminants.

Drainage from the Klamath Project integrates the runoff and tile drainage flows from the irrigated cropland and several million acres of surrounding watershed, as well as discharges from two national wildlife refuges (Tule Lake National Wildlife Refuge and the Lower Klamath National Wildlife Refuge). Water draining from farm fields in Tulelake Irrigation District provides much of the water supply to these refuges, so the effects of farming on water quality are important for their 
4 Sugarbeets have been an important crop in the Tulelake Irrigation District. Production in the Upper Klamath Basin was suspended after the 2000 harvest, at least for the time being, due to financial difficulties experienced by the sugar company.

\section{Sugarbeet plots are harvested at the UC Intermountain Re- search and Extension Center in Tulelake. A study found that the region's sugarbeets can be fertilized at very low rates, while the crop helps to remove excess nutrients from the soil.}

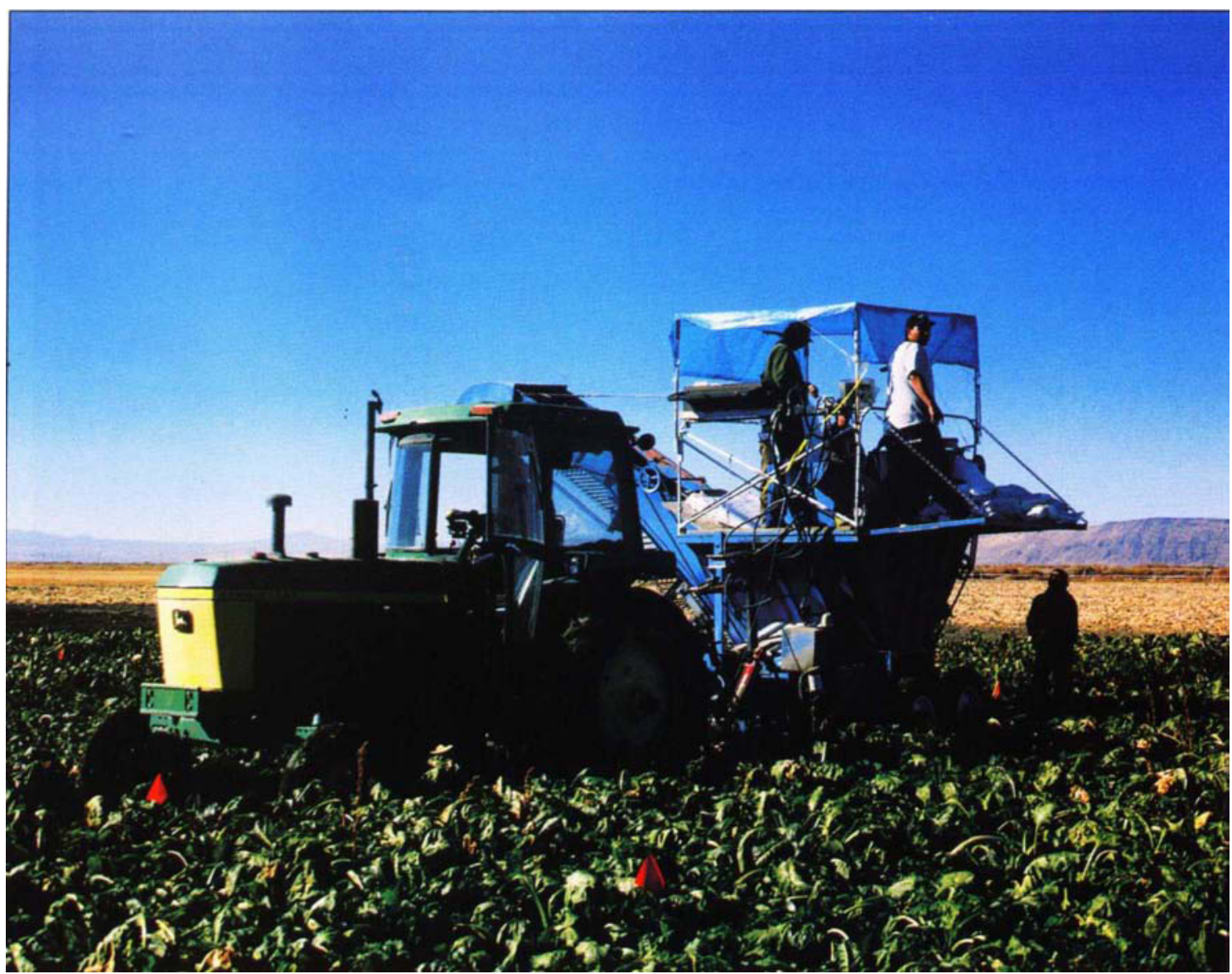

management as well. TMDLs at the Klamath Straits drain outlet could affect farming practices in the Tulelake Irrigation District.

Crops are grown on the wildlife refuges on a commercial basis and in part as food for wildlife, principally waterfowl, and to provide income for refuge management. Sugarbeets are a recent addition to cropping systems in the region. Between 8,000 and 9,000 acres of sugarbeets have been produced in the Upper Klamath Basin per year. Currently, sugarbeet production has been halted, at least temporarily, as the sugar company undergoes financial reorganization. There are 60,000 acres of sugarbeets statewide in California. This crop has been criticized by some environmentalists as inappropriate for the refuges because they are considered to have little value for waterfowl and because of misperceptions about the amount of pesticides used in their production.
But there are many ways in which crops and agriculture for crop production influence the environment. Focusing on waterfowl alone may result in the loss of other benefits, including use by other types of wildlife, particularly birds of prey, and the net removal of nutrients from the ecosystem.

Typically, phosphorus limits aquatic plant production in freshwater systems. Algae and other aquatic plants respond primarily to phosphorus additions to surface waters. If farming is contributing phosphorus in ecologically significant amounts to surface waters in the region, restrictions on farming practices are likely to be imposed. Phosphorus levels in surface waters entering the Tulelake Irrigation District are high, and area soils contain large amounts of organically bound phosphorus. Because of the unusual character of the soils in the district, which have large amounts of organic matter, there is a risk that fertilizer phosphorus may be lost in drainage waters if application rates significantly exceed crop needs. A fertilizer use survey of farmers and fertilizer suppliers that we conducted in the Tulelake area, in 1996 and 1997, suggested that farmers may be overusing phosphorus fertilizer in the production of sugarbeets.

Sugarbeets are deep-rooted, good at recovering nutrients from the soil profile, and have a long growing season, characteristics that favor the uptake of nutrients. However, to maintain the ability to produce sugarbeets or any other crop in the Tulelake area, fertilizer management practices must include an awareness of potential off-farm effects. The purpose of our research was to identify the minimum fertilizer phosphorus and nitrogen rates necessary for economic sugarbeet production on the soils of the Tulelake Irrigation District. 


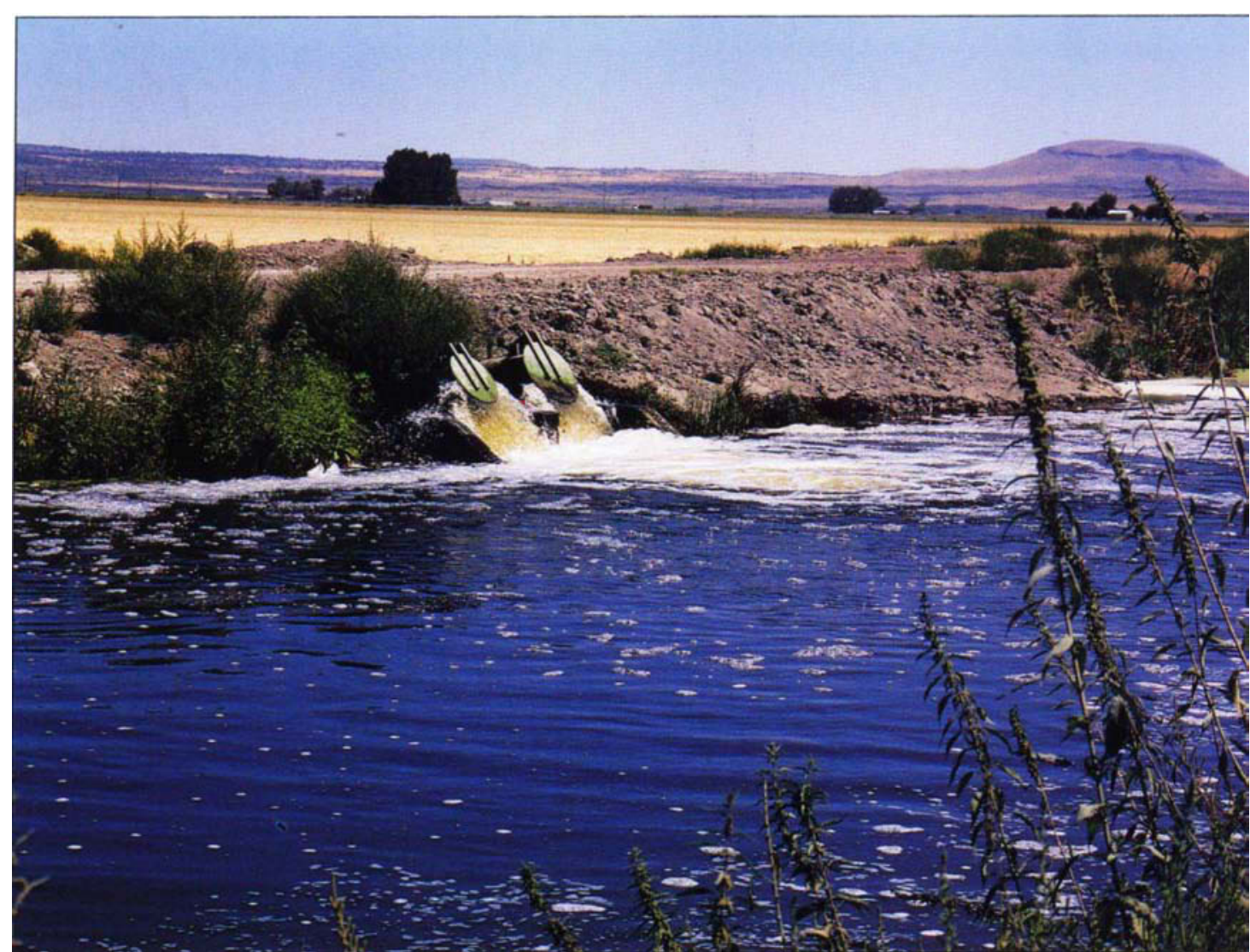

Under the Clean Water Act, total maximum daily loads (TMDLs) for the Klamath River watershed are likely to include nutrients such as nitrogen and phosphorus. Agricultural return flows to canal system in the Tulelake Irrigation District.

\section{Low rates of fertilizers tested}

A single sugarbeet cultivar ('Hilleshog Bighorn') was planted on May 6, 1998, and April 23, 1999, in small plots at the Intermountain Research and Extension Center at Tulelake, Calif. Prior to sugarbeets, fields had been planted to potato and barley crops in a rotation similar to that followed by many growers in the region. The preceding barley crop was uniformly fertilized at low rates. The soil at the site is a

Tulebasin mucky, silty, clay loam
TABLE 1. Impact of $N$ and $P$ on sugarbeet roots, sugar and recoverable sugar yields, 1998 and $1999^{*}$

\begin{tabular}{|c|c|c|c|}
\hline & Mean & $\begin{array}{l}\text { N effect } \\
\left(P>T^{*}\right)\end{array}$ & $\begin{array}{l}\text { P effect } \\
\left(P>T^{*}\right)\end{array}$ \\
\hline \multicolumn{4}{|c|}{1998} \\
\hline Root yield (t/ac) & 28.4 & $\begin{array}{l}-0.0093 \\
(0.200 \text { NSt) }\end{array}$ & $\begin{array}{l}-0.0169 \\
(0.094)\end{array}$ \\
\hline Sugar yield (lb/ac) & 10,380 & $\begin{array}{l}-1.915 \\
(0.518 \text { NS) }\end{array}$ & $\begin{array}{l}-9.205 \\
(0.024)\end{array}$ \\
\hline Recoverable sugar (lb/ac) & 9,290 & $\begin{array}{l}-2.836 \\
(0.344 \mathrm{NS})\end{array}$ & $\begin{array}{l}-9.093 \\
(0.031)\end{array}$ \\
\hline \multicolumn{4}{|c|}{1999} \\
\hline Root yield (t/ac) & 28.9 & $\begin{array}{l}-0.0083 \\
(0.162 \mathrm{NS})\end{array}$ & $\begin{array}{l}-0.0032 \\
(0.700)\end{array}$ \\
\hline Sugar yield (lb/ac) & 10,150 & $\begin{array}{l}-3.356 \\
(0.128 \text { NS) }\end{array}$ & $\begin{array}{l}-3.117 \\
(0.305 \text { NS) }\end{array}$ \\
\hline Recoverable sugar (lb/ac) & 8,770 & $\begin{array}{l}-3.74 \\
(0.065)\end{array}$ & $\begin{array}{l}-4.668 \\
(0.094)\end{array}$ \\
\hline
\end{tabular}

"Means and regression coefficients from the model $Y=b_{0}+b_{1} X$, and the probability that regression coefficients are significant for 1998 and 1999. $X=$ pounds of elemental $N$ or $P$.

†NS: Not Significant (mixed, mesic,

Andaqueptic

Haplaquolls). It is

similar to the Tulana and Capjac soils, and together these are found on a majority of the land farmed in the Tulelake Irrigation District (NRCS 1994). A factorial arrangement of five phosphorus $(0,10,20$, 30 and 60 pounds per acre) and five nitrogen fertilizer levels $(0,10,20,40$ and 80 pounds per acre) was established at planting. Phosphorus was applied at a uniform rate in groups of four plots at a time, and nitrogen treatments were randomized within phosphorus rates. These rates, alone and in combination, emphasized the lower rates of nitrogen and phosphorus fertilization.

Apart from fertilizer applications, plots were managed and irrigated uniformly throughout the season. In 1999 , soil samples ( 0 to 4 feet) were collected in 1-foot increments at the end of the season to analyze nutrient content. Roots were harvested and soil samples were collected in the third week of October in both years. At harvest, roots were analyzed by Spreckels Sugar in Woodland for sucrose and impurities. Petioles were also collected at harvest to determine if there were differences in petiole nitrate content and if these were correlated with fertilizer treatments. Data were analyzed using regression procedures in which root yield, sugar percent, and gross and recoverable sugar yields were compared to nitrogen and phosphorus application rates. Recoverable sugar is calculated from gross sugar yields, modified by the concentration of impurities including sodium, potassium and amino-nitrogen found in roots. 

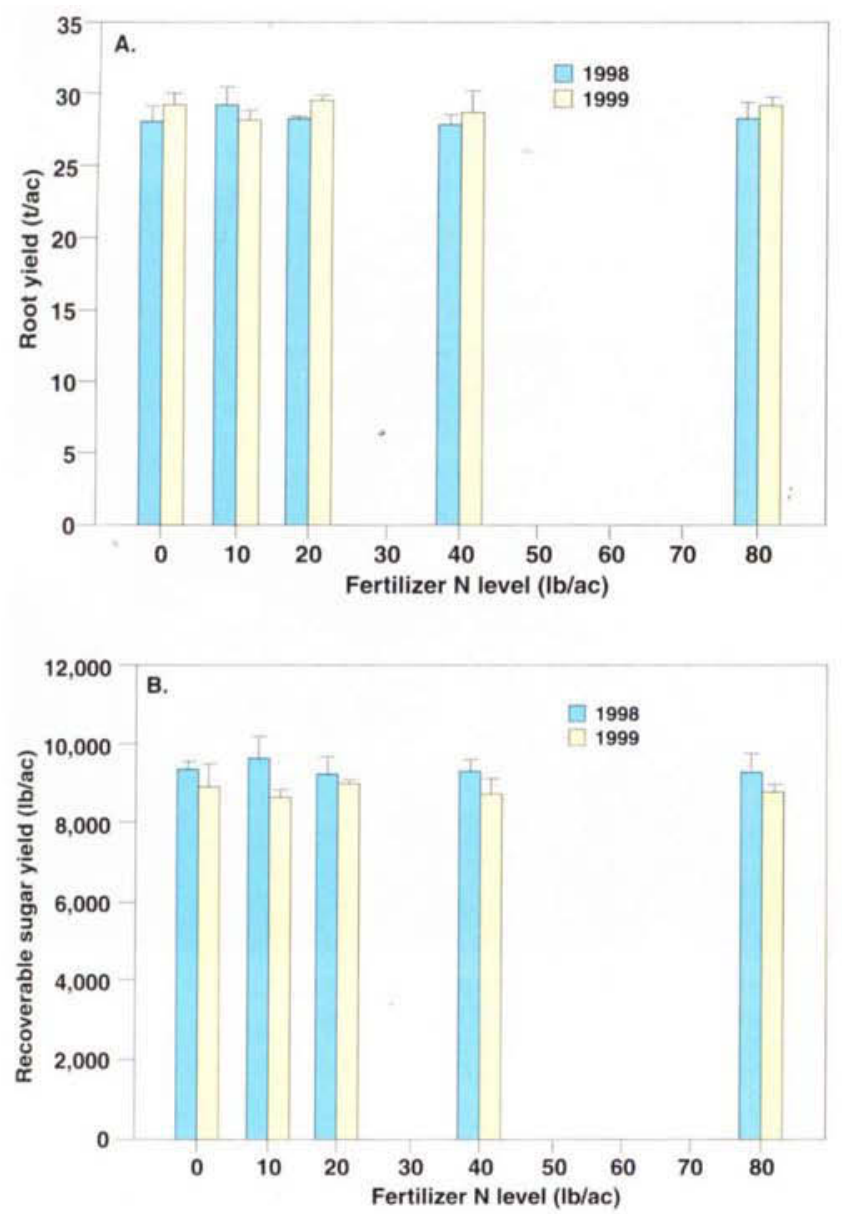

Fig. 1. (A) Root yield and (B) recoverable sugar yield as a function of nitrogen $(\mathrm{N})$ application rates. Error bars are standard errors in all figures.
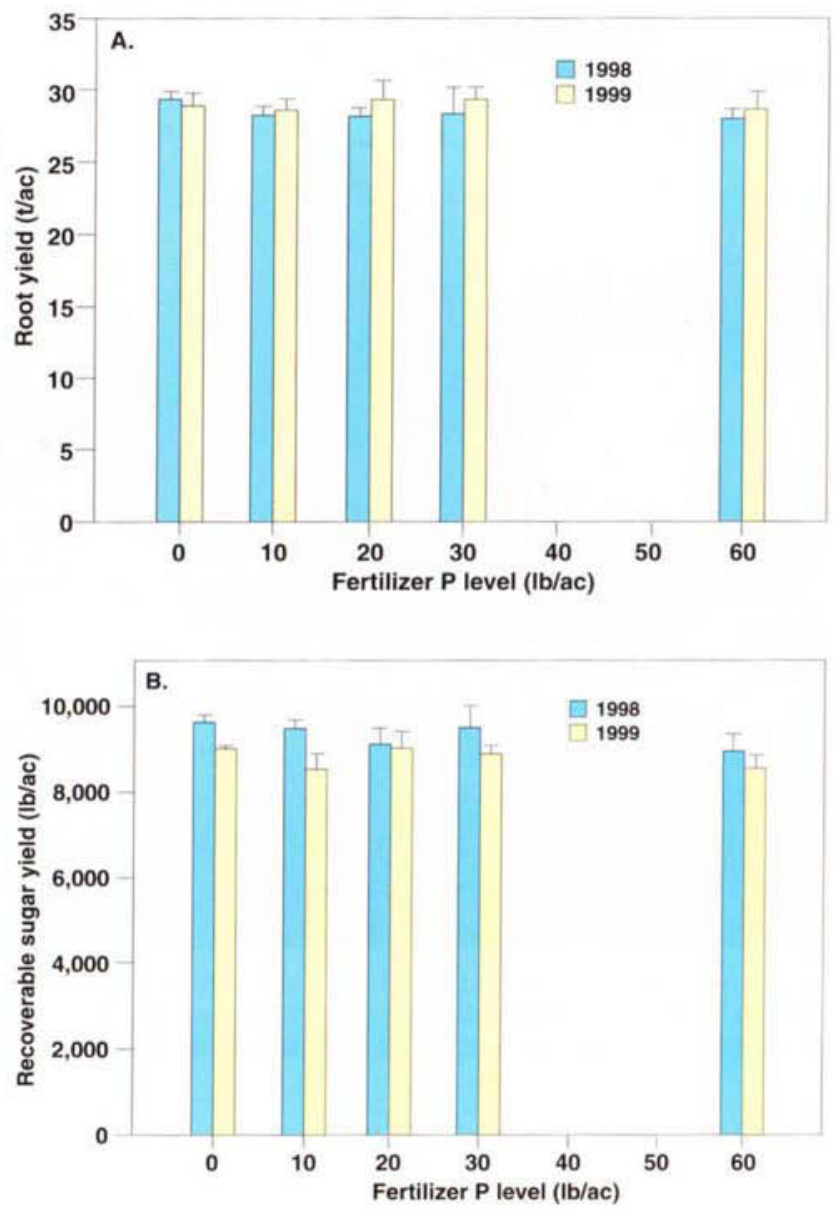

Fig. 2. (A) Root yield and (B) recoverable sugar yield as a function of phosphorus $(P)$ application rates.

\section{No response to fertilizer}

Mean root, gross sugar and recoverable sugar yields were similar in 1998 and 1999 (table 1). Crop response to applied fertilizer was not significant. There was little variation among plots in the trial, and little of the variation was attributable to fertilizer application. Furthermore, the data indicate that there was no discernable fertilizer response for root or recoverable sugar yields (figs. 1 and 2). Recoverable sugar estimates the amount of sucrose actually refined from beets. It is always lower than the gross sugar levels calculated for the crop. The greater the recovery rate, the more efficiently and profitably the factory operates, and the higher the profit-sharing returns to the growers.
Leaf petiole nitrate content is used to assess fertilizer management in sugarbeets. Early in the growing season, petiole nitrate-nitrogen $\left(\mathrm{NO}_{3}-\mathrm{N}\right)$ values often occur in the range of 10,000 to 15,000 parts per million (ppm) on a dry matter basis. At 6 weeks prior to harvest, petiole nitrate levels should have declined to $1,000 \mathrm{ppm}$ for the highest sucrose concentrations to be achieved in roots. Higher petiole levels late in the growing season are thought to stimulate leaf expansion and leaf initiation at the expense of sucrose accumulation in roots.

In most of California, sugarbeet fertilizer rates are adjusted to achieve end-of-season nitrate-nitrogen depletion based on local experience with petiole analysis, and fertilizer rates based on preplant soil analysis for nitrate-nitrogen (Hills et al. 1982). In these trials, petiole nitrate-nitrogen levels at harvest tended to be higher than the 1,000 ppm level recommended for the last 6 to 8 weeks prior to harvest (fig. 3). This was especially true in 1999 , indicating that nitrate levels were above desirable levels late in the growing season.

There seemed to be no clear relationship between nitrogen or phosphorus fertilization and petiole nitrate-nitrogen levels (fig. 3). In the rich soils of Tulelake, even some unfertilized plots had levels of $4,000 \mathrm{ppm}$ or greater in both years, suggesting that soil organic matter mineralization continued until the end of the growing season, and that sugarbeets continued to 


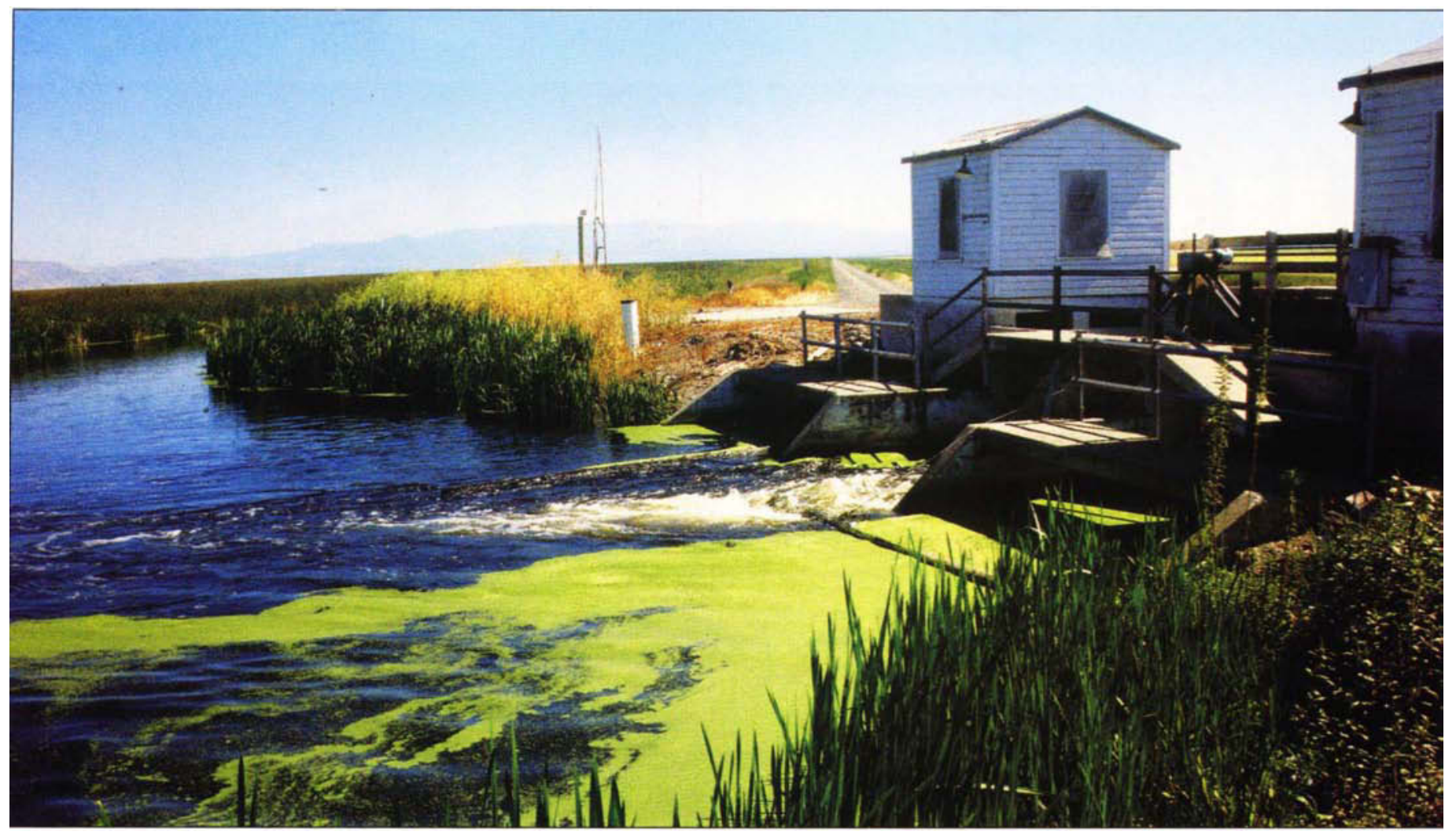

Soils in the Tulelake Irrigation District are rich in organic matter, which gives them high water-holding capacity and excellent drainage characteristics. Agricultural returns flow into the district's canal system, above. The average sugarbeet crop removes 20 to 30 pounds per acre of phosphorus and 120 to 150 pounds per acre of nitrogen.

take up nitrate-nitrogen until harvest.

Despite elevated petiole nitrate levels at harvest, sugar percentages were high compared to most locations in California. We hypothesize that this is due to late-season photosynthesis, when air temperatures are low and retard leaf canopy development despite the stimulus of abun- dant soil nitrogen, resulting instead in sucrose accumulation.

Soil samples collected at harvest were analyzed for nitrate-nitrogen and Olsen phosphorus (a measure of the amount of soil phosphorus potentially available to crops) (fig. 4). Nitratenitrogen in the soil profile at the end of the growing season in the highest application rate plots $(80$ pounds per acre) was significantly greater than in the control plots, particularly lower in the horizon. Because the beet yields in control plots were identical to those in the heavily fertilized plots, most of the fertilizer nitrogen applied was surplus to crop needs. Phosphorus behaved differently. Larger phosphorus fertilizer rates did not lead to enrichment of extractable phosphorus.
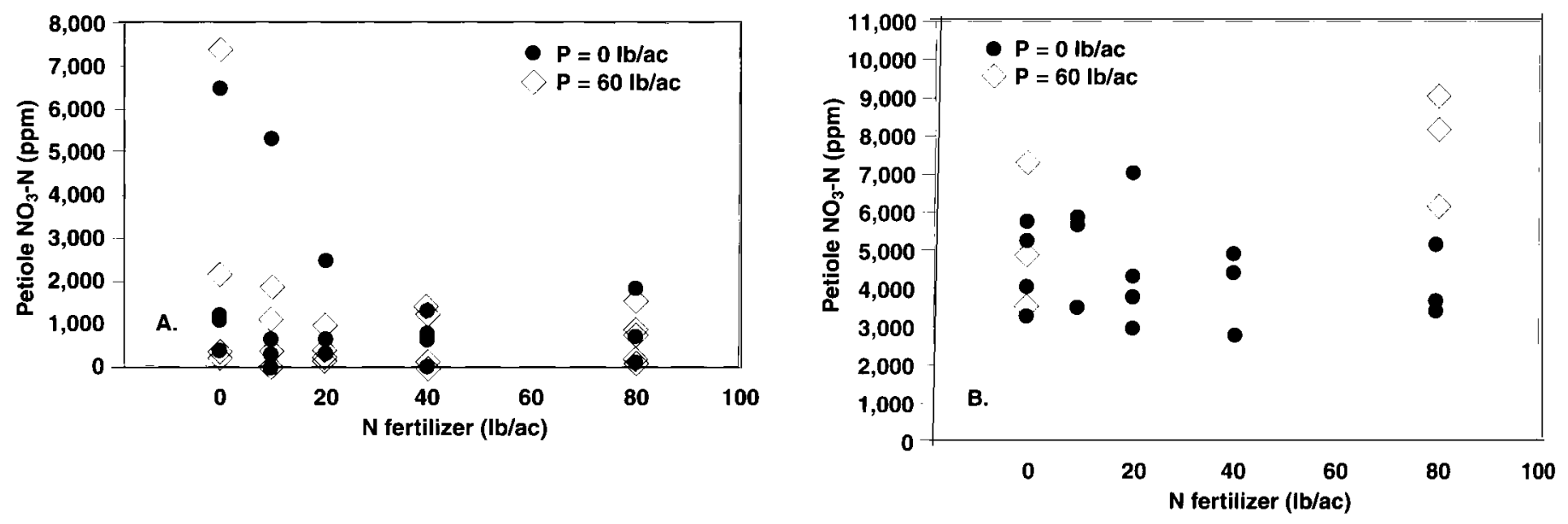

Fig. 3. Petiole nitrate-nitrogen $\left(\mathrm{NO}_{3}-\mathrm{N}\right)$ levels at harvest, with phosphorus $(P)$ and nitrogen (N) applied at different rates, in (A) 1998 and (B) 1999. 


\section{Removing nutrients with crops}

The soils reclaimed from the original Tule Lake bed are enriched and have both high water-holding capacity and excellent drainage characteristics. They are fertile, and farmers typically report underfertilizing grain crops, applying less in nitrogen and phosphorus than the crop removes. These trials indicate that sugarbeets need little if any supplemental fertilization to produce excellent agronomic yields when grown in this location. Furthermore, reduced expense for fertilizers improves profitability.

An average beet crop removes 20 to 30 pounds per acre of phosphorus in the harvested roots. Nitrogen removal is approximately 120 to 150 pounds per acre or more, depending on crop yield and impurities (Kaffka and Hills 1994). Based on results from these trials, beets can be used to reduce the risk of nitrogen and phosphorus loss in drainage waters, especially late in the season, by being fertilized at levels equal to or less than the amount removed in harvested root. Some nutrients are partitioned within the plant to leaves and crown tissues, which act as an organic matter addition to the soil. These residues re-enter the soil nutrient cycles and provide nitrogen and phosphorus to subsequent crops.

It is preferable for crops to take up soluble nutrients rather than to have them remain in the soil profile, where they are subject to leaching and increase the risk that soils will contribute excess nutrients to ground or surface waters. In the Tulelake Irrigation District, most drainage ends up in surface waters. Sugarbeets, with their deep root system and long growing season, can be used as part of a management system to reduce the threat of nutrient pollution of surface waters by taking up nutrients mineralized from the organic matter in these soils, or left over from previous crops such as potatoes.

The goal of crop fertility management, especially in environmentally sensitive areas, is to provide for crop nutrient requirements as precisely as possible, and for the crop to take up the majority of available nutrients throughout the growing season. This can be a challenging task, especially in soils with large amounts of organic matter. Organic matter mineralization is a complex function of many factors and occurs throughout the growing season, whether crop uptake removes these nutrients or not. Nutrients released from organic matter by mineralization, if not taken up by a crop, are subject to loss. Crops that mature early in the growing season do not take up nutrients mineralized from organic matter later in the season. By including sugarbeets in the cropping systems of the Tulelake region, nutrient uptake can be extended to the end of the growing season in some fields. By fertilizing beets at the minimum rates necessary for adequate economic returns, the risk of environmental loss of nutrients can be minimized. This helps to achieve both conservation and economic goals.

If farmers are to meet more restrictive regulatory standards, fertilizer recommendations must be refined locally. Older fertilization practices must be evaluated periodically to make certain that they apply to the location of concern and that they reflect changes in yield expectations, soils, and economic and regulatory constraints. This work, together with ongoing research and extension efforts for other crops by UC DANR, is part of a continuously updated source of information to growers.
$0 \mathrm{P}, 0 \mathrm{~N}$

$60 \mathrm{P}, 80 \mathrm{~N}(\mathrm{lb} / \mathrm{ac})$

A.

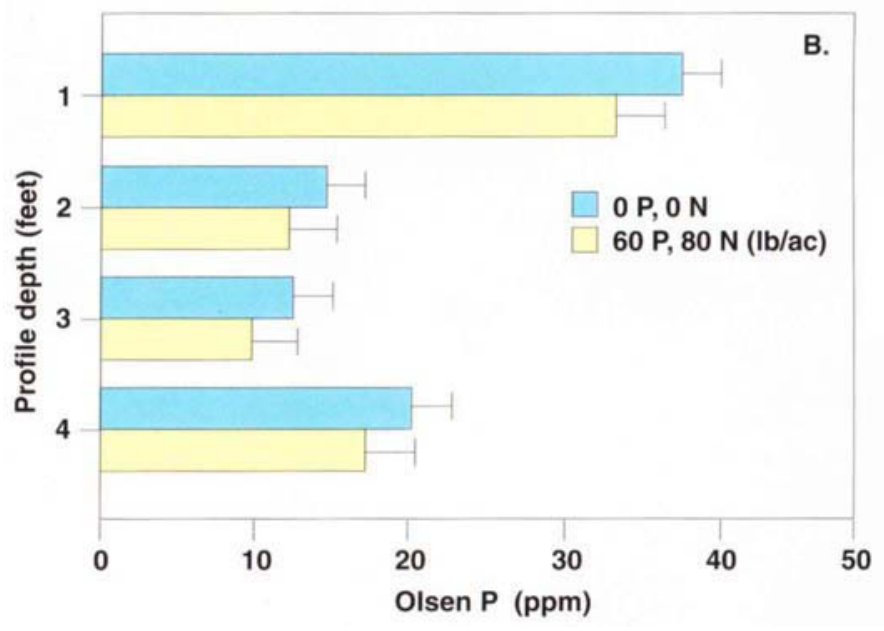

Fig. 4. Soil profile (A) nitrate-nitrogen (NO $-\mathrm{N}$ ) and (B) Olsen $\mathrm{P}$, with phosphorus $(P)$ and nitrogen $(N)$ applied at different rates, at harvest in 1999.

S.R. Kaffka is Associate Extension Specialist and G.R. Peterson is Staff Research Associate, Department of Agronomy and Range Science, UC Davis; and D. Kirby is Staff Research Associate, UC Intermountain Research and Extension Center, Tulelake. This research was funded in part by the California Sugarbeet Industry Research Committee.

\section{References}

Hills FJ, Sailsbury R, Ulrich A. 1982 Sugarbeet fertilization. DANR Bulletin 1891. Oakland, CA. 16 p.

Kaffka SR, Hills FJ. 1994. Sugarbeet. In: Encyclopedia of Agricultural Science 4:21523.

[NRCS] USDA Natural Resource Conservation Service. 1994. Soil Survey of Butte Valley-Tule Lake Area, CA. 

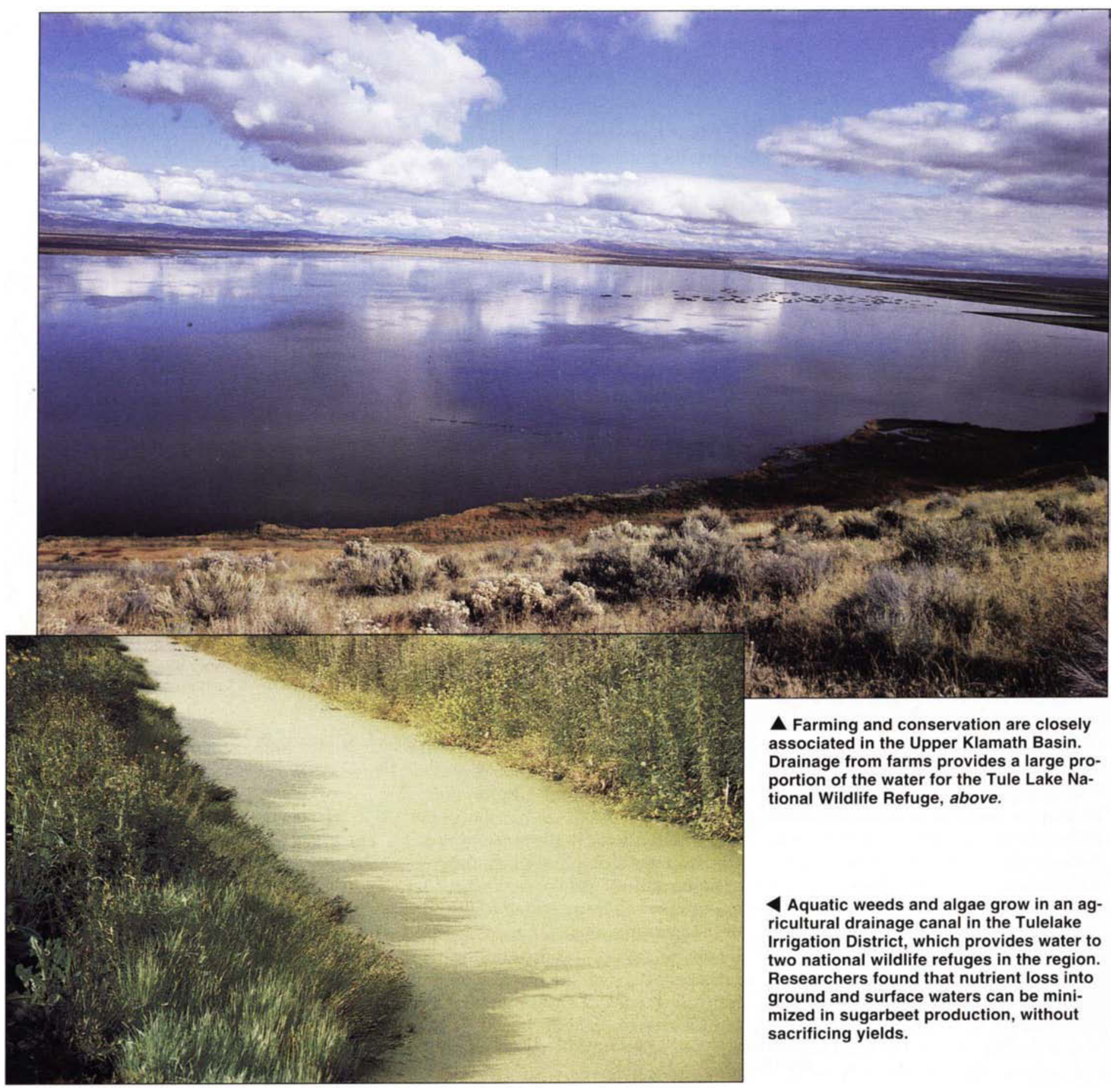

A Farming and conservation are closely associated in the Upper Klamath Basin. Drainage from farms provides a large proportion of the water for the Tule Lake National Wildlife Refuge, above.

\section{CALIFORNIA AGRICULTURE ASSOCIATE EDITORS}

Animal, Avian, Aquaculture \& Veterinary Sciences Jim Cullor

Christopher M. Dewees

Kathryn Radke

Barbara A. Reed

Economics \& Public Policy

Richard A. Howitt

Alvin Sokolow

\section{Food \& Nutrition}

Amy Block Joy

Sheri Zidenberg-Cherr

\section{Human \& Community}

Linda M. Manton

Land, Air \& Water Sciences Mark Grismer

John Letey

\section{Natural Resources}

Daniel W. Anderson

Lynn Huntsinger

Richard B. Standiford
Development http://danr.ucop.edu/calag/

CALAG@ucop.edu

PH: 510 987-0044

FAX: $510465-2659$

Aquatic weeds and algae grow in an agricultural drainage canal in the Tulelake Irrigation District, which provides water to two national wildlife refuges in the region. Researchers found that nutrient loss into ground and surface waters can be minimized in sugarbeet production, without sacrificing yields.

Pest Management

Donald L. Dahlsten

Timothy D. Paine

Michael K. Rust

Robert Washino

Plant Sciences

Jodie S. Holt

Lee F. Jackson 